\title{
EFFICACY OF RESISTANCE SELECTION TO VERTICILLIUM WILT IN STRAWBERRY (Fragaria $x$ ananassa Duch.) TISSUE CULTURE
}

\author{
Jadwiga Irena Żebrowska \\ Department of Genetics and Horticultural Plant Breeding, Faculty of Horticulture, University of Life Sciences, \\ Akademicka 15, 20-950 Lublin, Poland, e-mail: jadwiga.zebrowska@up.lublin.pl
}

Received: 29.11.2010

\begin{abstract}
The soil-borne pathogenic fungus Verticillium dahliae Kleb. causes economic losses in crops in temperate regions of the world and hence is the most studied species. Strawberry (Fragaria $x$ ananassa Duch.) belongs to plant species susceptible to Verticillium dahliae, although the response to infection caused by this pathogen is varied and depends on the cultivar. Due to a lack of efficient methods in Verticillium wilt elimination, the selection of genetically resistant plant material is a priority direction in breeding programs. Efficacy of resistance selection to Verticillium dahliae Kleb. in strawberry tissue culture was examined on the basis of response to in vitro infection by this pathogenic fungus in two tissue cultured strawberry cultivars, i.e. 'Filon' and 'Teresa'. Culture was conducted for 16 months in an environmentally controlled growth room at $18-20^{\circ} \mathrm{C}, 60-70 \%$ relative humidity and light intensity of

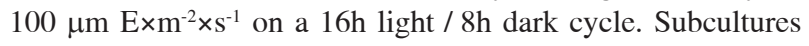
were proliferated every 6 weeks on modified Murashige and Skoog medium. Four hundred microplants from each tissue cultured cultivar were inoculated under in vitro conditions at the 4-leaf stage with a homogenate of liquid mycelium of Verticillium dahliae serving as the selecting agent. Disease symptoms were observed at $15,30,45,60$, and $75^{\text {th }}$ days post inoculation. The extent of leaf chlorosis was rated on a scale of 0-4.

At day $75^{\text {th }}$ post inoculation, the percentage of totally chlorotic plants in micropropagated cv. Teresa reached the value of $76.27 \%$, whereas the proportion of such plants in inoculated tissue cultured cv. Filon reached the value of $89.40 \%$. Also, the index of infection calculated for very severe disease symptoms in the subclone 'Teresa' reached the mean value lower when compared with that calculated for subclone 'Filon' (0.0962 and 0.1150 , respectively). These results suggested that the micropropagated cv. Teresa exhibited higher genetic resistance to the selecting agent in comparison with the tissue cultured cv. Filon, and it was consistent with field resistance of both cultivars to this pathogen. Therefore, the procedure of in vitro selection used in this study was quite efficient to distinguish varying genetic resistance to Verticillium dahliae in the two examined strawberry subclones, and can be recommended as
\end{abstract}

a suitable method for the estimation of susceptibility to Verticillium wilt in different strawberry genotypes.

Key words: strawberry, in vitro selection, subclones, genetic resistance, vascular disease, Verticillium dahliae

\section{INTRODUCTION}

Strawberry (Fragaria $x$ ananassa Duch.) belongs to plant species susceptible to a severe disease of the vascular system caused by Verticillium sp., soilborne fungi with worldwide distribution. Several species of Verticillium cause symptoms of Verticillium wilt, but Verticillium dahliae causes economic losses in crops in temperate regions of the world and hence is the most studied species. The pathogen can persist in soil for many years in the absence of a susceptible crop. Infection is through the roots, and management of the disease is difficult (B e r l a n g e r et al. 2000).

Verticillium wilt disease in strawberry is mainly caused by Verticillium dahliae Klebahn (Goth and W e b b, 1981; Wilhe lm, 1981; B hat and S u bb a r a o, 1999). The development of this disease can be strongly influenced by the timing of infection and cultivar susceptibility and is observed only after one or more cortical infections extend into the water conducting tissue (xylem). Once in the xylem, the pathogen produces spores that can move upward with water being transported from the root to the shoot. This is termed a systemic infection and usually leads to development of symptoms. Once an infected plant dies, the pathogen can grow more extensively and produce microsclerotia within decomposing crop residue, adding to the population of the pathogen in soil. Microsclerotia can survive from one to several years in soil, depending on cropping patterns and other conditions. 
Verticillium wilt symptoms vary somewhat among hosts, and none is absolutely diagnostic. Premature foliar chlorosis and necrosis as well as vascular discoloration in stems and roots, however, are characteristic of all hosts. In severely diseased plants, medium-tan discoloration of the vascular tissue is evident. When a strawberry plant is severely infected, the probability of it surviving to produce a crop is greatly reduced. Verticillium wilt often appears in new strawberry plantings as runners begin to form. In older plantings, the symptoms usually appear just prior to picking. The aboveground symptoms vary with the susceptibility of the cultivar and cannot be easily differentiated from those for red stele, black root rot, or winter injury. On infected strawberry plants, outer and older strawberry leaves droop, wilt, turn dry, and become reddish yellow or dark brown at the margins and between the veins.

Verticillium wilt must be managed through prevention, because no efficacious therapeutic measures are available. Although strawberry cultivars differ in their susceptibility to Verticillium wilt, none are sufficiently resistant to ensure complete control of the disease. Susceptibility to Verticillium wilt is now an important selection criterion in strawberry resistance breeding programs (Gordon and $\mathrm{Subbarao}$, 2007). Due to a lack of efficient methods in Verticillium wilt elimination, the selection of genetically resistant plant material is a priority direction in breeding programs.

In conventional plant breeding, disease resistance can be transferred to susceptible cultivars from genetic resistant forms via a multiple backcrossing method. Still, these procedures take up much time and need a large breeding area. Therefore, breeders are still looking for new alternative methods of resistance selection, which could shorten its time and considerably reduce the breeding area. Development of plant tissue culture techniques is a promising perspective in the solution of this problem, because it provides a unique opportunity to manipulate morphogenesis in a controlled environment, thus providing crop improvement with a powerful, complementary tool. Since the late 1970s, the process of in vitro selection has been applied to several cell culture systems to generate mutants with useful agronomic traits such as disease resistance. Heritable changes that result from in vitro procedures, named 'somaclonal variation' by L a r k i n and S cow croft (1981), may be used in breeding programs as a tool for selection of plants with increased resistance to fungal pathogens. Variation induced with respect to resistance to disease, including fungal, bacterial and viral diseases, was well reviewed by $\mathrm{V}$ a $\mathrm{n}$ d e n B ulk (1991). Besides, technology of in vitro selection is easy to use and not encumbered by intellectual property issues and social concerns currently inhibiting development of transgenic crops. Thus, it is an attractive complement to existing crop improvement strategies (J a y a s a n k a r and G r a y, 2003).

In this study, the efficacy of in vitro resistance selection to Verticillium dahliae Kleb. was tested in two tissue cultured strawberry cultivars.

\section{MATERIALS AND METHODS}

Response to the infection caused by Verticillium dahliae Kleb. in two micropropagated strawberry cultivars was examined in order to assess the efficacy of in vitro resistance selection to this pathogenic fungus. Microplants were obtained from meristematic tissue taken from runner tips as explants of two donor strawberry cultivars Filon and Teresa grown in the field. The Polish cultivar Filon selected in the Research Institute of Pomology and Floriculture (Skierniewice) from hybrid progeny $F_{1}$ obtained by crossing between cultivars Seal $\times$ Selva is recognized as moderately susceptible to Verticillium wilt. The cultivar Teresa (Redgauntlet $S_{1} \times$ Senga Sengana $S_{1}$ ), more resistant to this disease than cv. Filon under field conditions, was selected at the University of Life Sciences in Lublin. Explants were surface sterilized with sodium hypochlorite solution (1.0\%) in sterile distilled water for 10 minutes with the addition of the wetting agent. After rinsing in sterile distilled water, the explants were placed on modified Murashige and Skoog (1962) medium (Table 1) recommended for strawberry micropropagation; the $\mathrm{pH}$ of the medium was adjusted to 5.7.

Culture was conducted for 16 months in an environmentally controlled growth room at $18-20^{\circ} \mathrm{C}$, $60-70 \%$ relative humidity and light intensity of 100 $\mu \mathrm{m} \mathrm{E} \times \mathrm{m}^{-2} \times \mathrm{s}^{-1}$ on a $16 \mathrm{~h}$ light/ $8 \mathrm{~h}$ dark cycle. Subcultures were proliferated on MS medium (Table 1) every 6 weeks until the number of microplants appropriate for selection was obtained. The microplants were rooted for 4 weeks on basal medium (Table 1) without growth regulators, and then four hundred microplants from each subclone were inoculated under in vitro conditions at the 4-leaf stage with a homogenate of liquid mycelium with conidia of Verticillium dahliae serving as the selecting agent.

The strawberry isolate of cv. Elsanta no. 1093 of V.dahliae from Pathogen Gene Bank (Poznań) was used throughout this study. The isolate was grown on potato-dextrose agar medium (PDA) in Petri plates. The homogenate of liquid mycelium with conidia was prepared from the fungal culture grown for 3 weeks by flooding the surface of culture with sterile distilled water. After that, the obtained mycelial suspension was homogenized and diluted with sterile distilled water before inoculation to an appropriate concentration (density of conidia suspension $10^{5} \times \mathrm{ml}^{-1}$ ). 
$100 \mathrm{ml}$ of such prepared inoculum was used for inoculation of every 30 microplants. The roots of the microplants were dipped for approximately $1 \mathrm{~min}$ in the homogenate of liquid mycelium, after that, the inoculated microplants were placed in $10 \mathrm{~cm}$ Petri plates (3 microplants per Petri plate) on agar-water medium (50 $\mathrm{ml}$ in each plate) and kept in an environmentally controlled growth room at the same temperature and light intensity. The inoculum for mock-inoculation of four hundred control microplants of each subclone was prepared by flooding the surface of 3 week potatodextrose agar medium (without the pathogen) placed in Petri dishes with sterile distilled water. The mockinoculation of control microplants was done accordingly to the same above given procedure. During the experiment, in vitro selected microplants were kept on the same agar-water medium.

The extent of leaf chlorosis was observed as the disease symptoms at $15,30,45,60,75^{\text {th }}$ days post inoculation (dpi) in the inoculated microplants and was rated on a scale of $0-4$. The same observations were done for the control microplants. Also, the infection index was estimated on the basis of the extent of disease symptoms observed on subsequent days post inoculation. The obtained results were statistically analysed.

\section{RESULTS}

Disease symptoms developed gradually, becoming evident after day $15^{\text {th }}$ post inoculation. Symptoms observed in the V.dahliae-inoculated microplants of both subclones included the increased level of leaf chlorosis (Table 2), which developed more rapidly than in the mock-inoculated control plants (Table 3, Fig. 1a,b,c).

During the first $15^{\text {th }}$ days post inoculation, the highest percentage of microplants without disease symptoms was observed in the subclone of 'Filon' $(75.83 \%)$, whereas in the subclone of 'Teresa' the proportion of these plants reached a half lower value (Table 2). After the first $15^{\text {th }}$ days post inoculation, the highest percentage of microplants with chlorosis affecting $1^{\text {st }}$ leaf was observed in the subclone 'Teresa', whereas in the subclone 'Filon' this value was considerably lower (Table 2). In both subclones, the proprotion of microplants with disease symptoms affecting $2^{\text {nd }}$ leaves was comparable. Besides, in the subclone 'Teresa' microplants with chlorosis affecting $3^{\text {rd }}$ leaves were observed at the same level, reaching the value of $4.51 \%$ (Table 2). No microplants with disease symptoms affecting $4^{\text {th }}$ leaves were observed in this subclone. On the contrary, at $15^{\text {th }}$ days post inoculation (dpi) in the subclone 'Filon' there was found an insignificant proportion (below 1\%) of microplants with disease symptoms affecting $4^{\text {th }}$ leaves. In both control subclones, at $15^{\text {th }}$ dpi the percentage of microplants without chlorosis reached a considerably higher value than the one estimated for the infected subclones (Table 3).

At day $30^{\text {th }}$ post inoculation, no microplants without disease symptoms were observed in both subclones. The percentage of microplants with chlorosis affecting $1^{\text {st }}$ leaf and $2^{\text {nd }}$ leaves was the highest in both subclones. Microplants with disease symptoms affecting $3^{\text {rd }}$ and $4^{\text {th }}$ leaves were also observed, but their proportion was considerably lower (Table 2 ). In the control subclones, at day $30^{\text {th }}$ post mock-inoculation (dpmi) the percentage of microplants without chlorosis was still very high, although there was observed a small percentage of microplants with chlorosis affecting $1^{\text {st }}$ and more leaves (Table 3 ).

At day $45^{\text {th }}$ post inoculation, a considerable decrease in the proportion of microplants with chlorosis affecting $1^{\text {st }}$ leaf was observed, and an increase in the proportion of microplants with chlorosis affecting $3^{\text {rd }}$ and $4^{\text {th }}$ leaves was visible in both subclones. The percentage of microplants with chlorosis affecting $4^{\text {th }}$ leaves was considerably higher in the subclone 'Filon' than in the subclone 'Teresa' $(23.61 \%$ and $7.90 \%$, respectively). As shown in Table 3 , in the control subclones at $45^{\text {th }}$ dpmi the percentage of microplants without chlorosis was still very high and the proportion of microplants with chlorosis affecting the successive parts of the microplant was very low.

At day $60^{\text {th }}$ post inoculation the proportion of totally chlorotic microplants drastically increased in both subclones, reaching the values of $55.55 \%$ for the subclone 'Filon' and $33.33 \%$ for the subclone 'Teresa'. Besides, in this subclone there was observed the highest percentage of microplants with chlorosis affecting 3 leaves, whereas in the subclone 'Filon the percentage of such microplants reached a more than twice lower value $(57.62 \%$ and $24.44 \%$, respectively). Although in the control subclones at $60 \mathrm{dpmi}$ the percentage of microplants without chlorosis decreased below $90 \%$, but in thh the infected subclones, there was observed a low proportion of microplants with chlorosis affecting the successive parts of the parts of the plant, reaching the mean value of $12.29 \%$ (Table 3 ).

At the end of experiment, at $75^{\text {th }}$ dpi in both subclones there was observed the highest percentage of totally chlorotic microplants. In the subclone 'Teresa', this value reached $76.27 \%$, and in the subclone 'Filon' $89.40 \%$ (Table 2). In control subclones, at $75^{\text {th }} \mathrm{dpmi}$ the proportion of totally chlorotic microplants was nearly $10^{\text {th }}$ times lower in comparison with infected subclones (Table 3). In spite of the high proportion of totally chlorotic microplants in both subclones, there were observed microplants that survived pathogen pressure at $75^{\text {th }}$ dpi. Their percentage in the subclone 'Filon' reached a total value of $10.54 \%$ and in subclone 'Teresa' this value was higher $(23.72 \%)$ (Table 2). 
Table 4 shows the index of infection of both inoculated subclones. The calculated values were different on successive days post inoculation and depended on the individual subclone's resistance to the applied selecting agent. It was observed that in the subclone 'Filon' the mean value of the infection index evaluated for no symptoms of disease reached a lower value in comparison to this value calculated for the subclone 'Teresa' (0.0366 and 0.0428, respectively).

The means evaluated for very mild and mild symptoms reached higher values in the subclone 'Filon'. Although in the case of the infection index calculated for severe symptoms its mean value was higher in the subclone 'Teresa', but in this subclone the mean value assessed for very severe symptoms of disease was lower in comparison to the one evaluated for the subclone 'Filon' in this experiment (0.0962 and 0.1150 , respectively).

Analysis of variance (Table 5) showed highly significant differences between values of the infection index for evaluated combinations (subclones). Although, as shown in Table 5.a, the mean values of the index were not significantly differentiated between both inoculated subclones, but highly significant differences were estimated between these values and the mean index of control combinations.

Table 1.

Composition of modified MS medium for strawberry proliferation

\begin{tabular}{lrlr}
\hline \multicolumn{1}{c}{ Components } & $\begin{array}{r}\text { Amount } \\
\left(\mathrm{mg} \times \mathrm{dm}^{-3}\right)\end{array}$ & \multicolumn{1}{c}{ Components } & \multicolumn{1}{c}{$\begin{array}{c}\text { Amount } \\
\left(\mathrm{mg} \times \mathrm{dm}^{-3}\right)\end{array}$} \\
\hline Macronutrients & & Vitamins & \\
$\mathrm{KNO}_{3}$ & 1900.000 & Nicotinic acid (vit. PP) & 0.500 \\
$\mathrm{KH}_{2} \mathrm{PO}_{4}$ & 170.000 & Pirydoxine $-\mathrm{HCl}$ (vit. B6) & 0.500 \\
$\mathrm{NH}_{4} \mathrm{NO}_{3}$ & 1650.000 & Thiamine $-\mathrm{HCl}$ ( vit. B1) & 0.400 \\
$\mathrm{MgSO}_{4} \times \mathrm{H}_{2} \mathrm{O}$ & 370.000 & Growth regulators & \\
$\mathrm{CaCl}_{2}$ & 332.200 & Gibberellic acid (GA3) & 0.010 \\
$\mathrm{Micronutrients}$ & & Indole-3-acetic acid (IAA) & 1.000 \\
$\mathrm{H}_{3} \mathrm{BO}_{3}$ & 6.200 & Benzylaminopurine (BAP) & 1.000 \\
$\mathrm{MnSO}_{4} \times \mathrm{H}_{2} \mathrm{O}$ & 16.900 & Organics & \\
$\mathrm{CoCl}_{2} \times 6 \mathrm{H}_{2} \mathrm{O}$ & 0.025 & myo-Inositol & 6000.000 \\
$\mathrm{FeNaEDTA}_{\mathrm{ZnSO}} \times 7 \mathrm{H}_{2} \mathrm{O}$ & 40.300 & Agar-agar & 20000.000 \\
$\mathrm{KJ}$ & 8.600 & Sucrose & \\
\hline
\end{tabular}

Table 2.

Percentage of microplants with chlorosis in strawberry subclones on subsequent days post inoculation

\begin{tabular}{|c|c|c|c|c|c|c|}
\hline \multirow{2}{*}{ Subclones } & \multirow{2}{*}{$\begin{array}{c}\text { Scale of chlorosis } \\
(0 .-4 .)\end{array}$} & \multicolumn{5}{|c|}{ Days post inoculation } \\
\hline & & 15. & 30. & 45. & 60. & 75. \\
\hline \multirow{5}{*}{ 'Filon' } & 0. & 75.83 & 0.00 & 0.00 & 0.00 & 0.00 \\
\hline & 1. & 18.05 & 47.70 & 13.30 & 0.55 & 0.00 \\
\hline & 2. & 5.83 & 38.05 & 34.40 & 19.44 & 2.77 \\
\hline & 3. & 0.17 & 8.61 & 28.61 & 24.44 & 7.77 \\
\hline & 4. & 0.12 & 5.55 & 23.61 & 55.55 & 89.40 \\
\hline \multirow{5}{*}{ 'Teresa' } & 0. & 31.07 & 0.00 & 0.00 & 0.00 & 0.00 \\
\hline & 1. & 59.32 & 47.45 & 2.25 & 0.00 & 0.00 \\
\hline & 2. & 5.08 & 36.72 & 42.37 & 9.03 & 0.00 \\
\hline & 3. & 4.51 & 15.25 & 47.45 & 57.62 & 23.72 \\
\hline & 4. & 0.00 & 0.56 & 7.90 & 33.33 & 76.27 \\
\hline
\end{tabular}

Legend to Table 2. and 3.

Scale of chlorosis

0 . - no chlorotic leaves

1. $-1^{\text {st }}$ chlorotic leaf

2. $-2^{\text {nd }}$ chlorotic leaves

3. $-3^{\text {rd }}$ chlorotic leaves

4. $-4^{\text {th }}$ chlorotic leaves 
Table 3.

Percentage of microplants with chlorosis in control strawberry subclones on subsequent days post mock-inoculation

\begin{tabular}{ccccccc}
\hline \multirow{2}{*}{$\begin{array}{c}\text { Control } \\
\text { subclones }\end{array}$} & $\begin{array}{c}\text { Scale of chlorosis } \\
(0 .-4 .)\end{array}$ & 15. & 30. & 45. & 60. & 75. \\
\cline { 3 - 7 } & 0. & 95.54 & 93.86 & 90.01 & 87.22 & 84.40 \\
\multirow{2}{*}{ 'Filon' } & 1. & 2.46 & 3.00 & 1.00 & 0.80 & 0.00 \\
& 2. & 1.00 & 1.24 & 3.50 & 2.08 & 1.30 \\
& 3. & 0.80 & 1.10 & 3.49 & 2.40 & 5.00 \\
& 4. & 0.20 & 0.90 & 2.00 & 7.60 & 9.30 \\
\hline \multirow{2}{*}{ 'Teresa' } & 0. & 96.96 & 94.68 & 89.99 & 88.30 & 87.00 \\
& 1. & 2.00 & 1.50 & 1.01 & 0.00 & 0.00 \\
& 2. & 0.53 & 2.00 & 4.00 & 1.70 & 0.00 \\
& 3. & 0.50 & 1.22 & 3.00 & 6.00 & 5.00 \\
\end{tabular}

Table 4.

Index of infection in strawberry subclones

\begin{tabular}{|c|c|c|c|c|c|c|c|}
\hline \multirow{2}{*}{ Subclones } & \multirow{2}{*}{$\begin{array}{c}\text { Range of } \\
\text { susceptibility } \\
(0 .-4 .) \\
\end{array}$} & \multicolumn{5}{|c|}{ Index of infection (on subsequent days post inoculation) } & \multirow{2}{*}{ Means } \\
\hline & & 15. & 30. & 45. & 60. & 75. & \\
\hline \multirow{5}{*}{ 'Filon' } & 0 . & 0.1832 & 0.0000 & 0.0000 & 0.0000 & 0.0000 & 0.0366 \\
\hline & 1. & 0.1479 & 0.2494 & 0.1153 & 0.0054 & 0.0000 & 0.1036 \\
\hline & 2. & 0.0549 & 0.2357 & 0.2256 & 0.1566 & 0.0269 & 0.1399 \\
\hline & 3. & 0.0016 & 0.0786 & 0.2042 & 0.1846 & 0.0716 & 0.1081 \\
\hline & 4. & 0.0011 & 0.0519 & 0.1804 & 0.2469 & 0.0947 & 0.1150 \\
\hline \multirow{5}{*}{$\begin{array}{l}\text { 'Filon' } \\
\text { control }\end{array}$} & 0. & 0.0426 & 0.0576 & 0.0899 & 0.1114 & 0.1316 & 0.0866 \\
\hline & 1. & 0.0239 & 0.0291 & 0.0099 & 0.0079 & 0.0000 & 0.0141 \\
\hline & 2. & 0.0099 & 0.0122 & 0.0337 & 0.0203 & 0.0128 & 0.0178 \\
\hline & 3. & 0.0079 & 0.0108 & 0.0336 & 0.0234 & 0.0475 & 0.0246 \\
\hline & 4. & 0.0019 & 0.0089 & 0.0196 & 0.0702 & 0.0843 & 0.0369 \\
\hline \multirow{5}{*}{ 'Teresa' } & 0 . & 0.2141 & 0.0000 & 0.0000 & 0.0000 & 0.0000 & 0.0428 \\
\hline & 1. & 0.2413 & 0.2493 & 0.0219 & 0.0000 & 0.0000 & 0.1025 \\
\hline & 2. & 0.0482 & 0.2323 & 0.2441 & 0.0821 & 0.0000 & 0.1213 \\
\hline & 3. & 0.0430 & 0.1292 & 0.2493 & 0.2441 & 0.1809 & 0.1693 \\
\hline & 4. & 0.0000 & 0.0055 & 0.0727 & 0.2222 & 0.1809 & 0.0962 \\
\hline \multirow{5}{*}{$\begin{array}{l}\text { 'Teresa' } \\
\text { control }\end{array}$} & 0. & 0.0294 & 0.0503 & 0.0900 & 0.1033 & 0.1131 & 0.0772 \\
\hline & 1. & 0.0196 & 0.0147 & 0.0099 & 0.0000 & 0.0000 & 0.0088 \\
\hline & 2. & 0.0052 & 0.0196 & 0.0384 & 0.0167 & 0.0000 & 0.0159 \\
\hline & 3. & 0.0049 & 0.0120 & 0.0291 & 0.0564 & 0.0475 & 0.0300 \\
\hline & 4. & 0.0000 & 0.0059 & 0.0196 & 0.0384 & 0.0736 & 0.0275 \\
\hline
\end{tabular}

Legend to Table 4.

0 . - no symptoms

1. - very mild symptoms

2. - mild symptoms

3. - severe symptoms

4. - very severe symptoms

Table 5 .

Analysis of variance for the index of infection in strawberry subclones

\begin{tabular}{lcccc}
\hline \multicolumn{1}{c}{ Source of variation } & Degrees of freedom & Sum of square (SS) & Mean square (MS) & Femp \\
\hline Combinations (subclones) & 3 & 0.136834 & 0.045611 & $7.21^{* *}$ \\
Error & 96 & 0.607252 & 0.006326 & \\
Total & 99 & 0.744086 & & \\
\hline
\end{tabular}


Table 5a.

Mean index of infection in strawberry subclones

\begin{tabular}{ccccc}
\hline Subclones (combinations) & 'Filon' & 'Filon' control & 'Teresa' & 'Teresa' control \\
\hline Mean index & $0.1007 \mathrm{~b}^{* *}$ & $0.0360 \mathrm{a}$ & $0.1064 \mathrm{~b}$ & $0.0319 \mathrm{a}$ \\
\hline
\end{tabular}

** Means followed by the same letter are not significantly different $(\mathrm{P}=0.01)$ as determined by Duncan's test
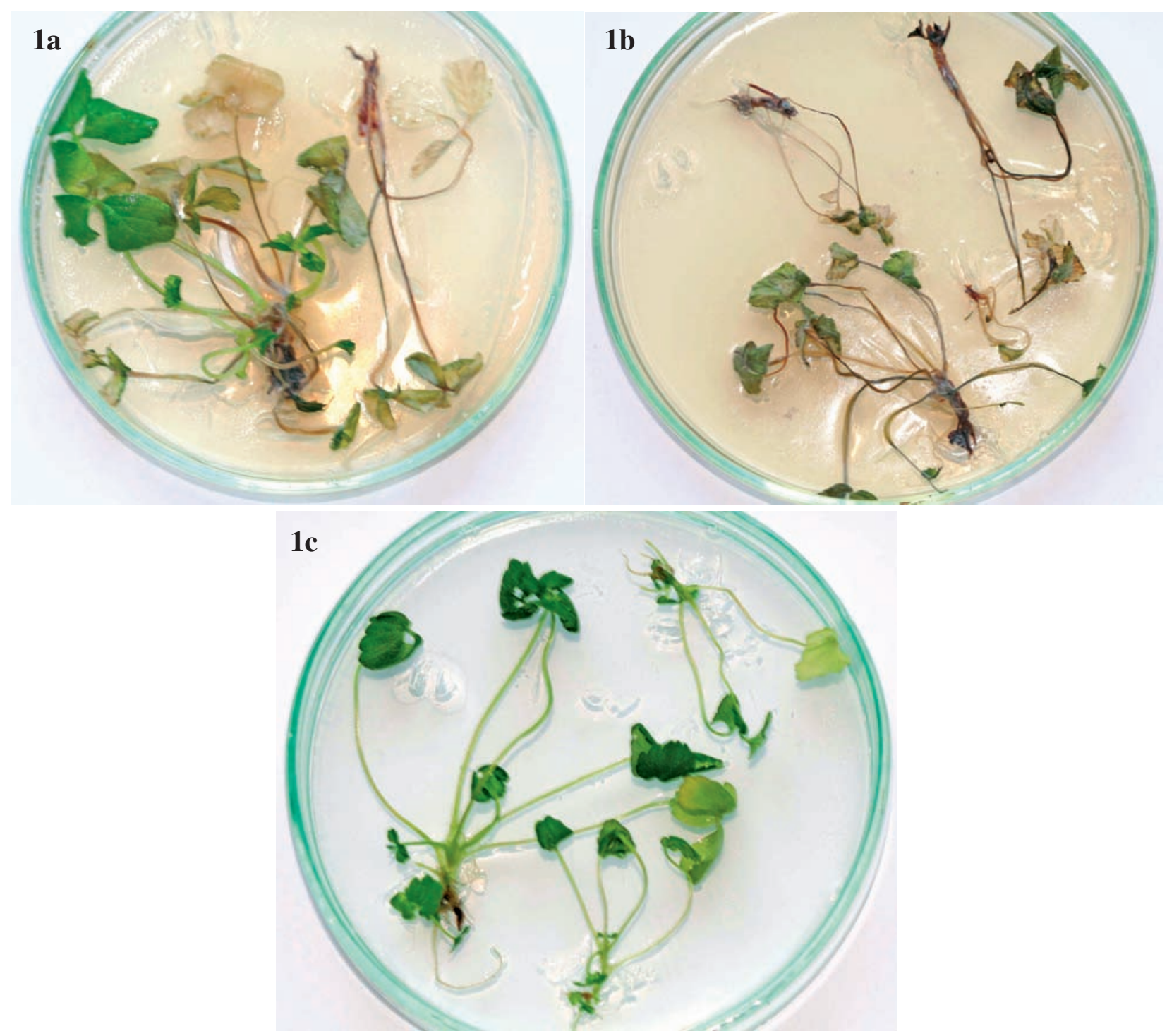

Fig. 1 Development of disease symptoms in strawberry microplants inoculated in vitro by Verticillium dahliae Kleb.

$1 \mathrm{a}-$ at $45^{\text {th }} \mathrm{dpi}$;

$1 \mathrm{~b}-$ at $75^{\text {th }} \mathrm{dpi}$;

$1 \mathrm{c}-$ control microplants at $75^{\text {th }} \mathrm{dpi}$

\section{DISCUSSION}

According to S o w i k (2001), the fungus Verticillium dahliae prepared for inoculation as a homogenate of liquid mycelium caused inhibition in plant height and shoot development in in vitro infected plants, though the intensity of this process was different. In the present study, a similar response to in vitro infection caused by this pathogenic fungus was also observed in both subclones. The extent of leaf chlorosis was different and depended on the subclone. In both infected subclones, at $75^{\text {th }}$ dpi microplants that had survived pathogen pressure were selected (Table 2). Although chlorosis developed more rapidly in the infected microplants of the subclone 'Teresa', when compared 
with the subclone 'Filon', particularly during the first $15^{\text {th }}$ days post-inoculation, but at the end of experiment after $75^{\text {th }}$ dpi, microplants of the subclone 'Teresa' remained more resistant to the pathogenic fungus. This was confirmed by the lower proportion of totally chlorotic microplants and the higher proportion of microplants that survived pathogen pressure, in comparison with the response to infection observed in the subclone 'Filon'. This result of the experiment is in agreement with the results obtained by Z u r a w i c z (2005) who found that 'Filon' was more susceptible to Verticillium wilt than cv. 'Teresa' in the field conditions.

The index of infection calculated on the basis of the severity of disease symptoms observed on subsequent days post inoculation also confirmed this statement. Although the mean values of the infection index in both selected subclones were not significantly different, as was revealed by the analysis of variance, but the infection index assessed for very severe disease symptoms in the subclone 'Teresa' reached the mean value lower when compared with its value calculated for the subclone 'Filon'. Also, the higher mean value of the infection index calculated for no disesase symptoms in the subclone 'Teresa' revealed its lower susceptibility to pathogen pressure. These obtained results suggested that the subclone 'Teresa' was more resistant to V.dahliae in this experiment in comparison to the subclone 'Filon'.

Investigations conducted by Sow ik (2002) were also in agreement with the statement that susceptibility to infection by Verticillium dahliae in strawberry subclones under in vitro conditions was similar to their response to infection in the field conditions. Thus, the procedure of in vitro selection used in this study was quite efficient to distinguish variability in genetic resistance to the selecting agent in the analysed plant material and thus can be recommended as an alternative and useful method in resistance breeding programs. Also, C h a leff (1983), J a in (2001) and Sow ik (2002) pointed out that in vitro selection is a useful tool in identifying plants resistant or tolerant to stresses produced by phytotoxins from pathogens, herbicides, cold temperature, aluminium, manganese and salt toxicity. Usually, cells are subjected to a suitable selection pressure in vitro to recover any variant lines that have developed resistance or tolerance to the stress followed by regeneration of plants from the selected cell. This approach presumes that tolerance or resistance operating at the unorganized cellular level can act, to some degree of effectiveness, in the whole plant. The trait can be transferred to other plants if the tolerance/resistance has a genetic basis.

In strawberry, many scientists have applied an in vitro screening system to obtain plants resistant or tolerant to Alternaria alternata ( $\mathrm{T}$ a k a has $\mathrm{h} \mathrm{i}$ et al. 1992), Botrytis cinerea (Orlando et al.1997), Colletotrichum acutatum (D a miano et al. 1997; $\mathrm{Hammerschlag}$ et al. 2006), Fusarium oxysporum (T o y o d a et al. 1991), Phytophthora cactorum (M a s et al. 1993; Sowik et al. 2001), Phytophthora fragariae (M a a s et al. 1993), P.nicotianae var. parasitica (A m i m o t o, 1992), Rhizoctonia fragariae (O r l a n d o et al. 1997) and to Verticillium dahliae (Sowik et al. 2001, 2003). Hammerschlag et al. (2006) used an in vitro screening system to evaluate the strawberry cultivars 'Chandler', 'Delmarvel', 'Honeoye', Latestar', 'Pelican' and 'Sweet Charlie' propagated in vitro.

The occurance of variation in plants regenerated from in vitro cultures has been reported for morphological and yield variation in micropropagated strawberries (Grah a m, 2005). M o ore et al. (1991) observed variability among micropropagated subclones of 'Olympus' which were most likely transient responses to the micropropagation environment, not genetic. Although somaclonal variation is not desirable for commercial micropropagation, it is a valuable tool in plant breeding wherein variation in tissue-culture regenerated plants from somatic cells can be used in the development of crops with novel traits. As was pointed out by $\mathrm{Grah}$ a m (2005), genetic stability during micropropagation is controlled by numerous factors, including duration of culture. Long term culture tends to produce genetic as well as epigenetic variations in many species (Larkin and Scowcroft, 1981). In the present study, the culture was conducted for 16 months, so it was quite possible that the occurrence of spontaneously induced genetic variation in the selected subclones resulted from the long time culture. Investigations conducted by S ow i k (2002) also revealed the presence of somaclonal variation in selected in vitro strawberry somaclones. In conclusion, it can be stated that in vitro techniques are important tools for modern plant improvement programs to introduce new traits into selected plants, also recommended for plants created by biotechnological methods.

\section{REFERENCES}

A mi moto K., 1992. Selection in strawberry with resistance to phytophthora root rot for hydroponics. Acta Hortic. 319: 273-278.

Berlanger I., Powels on M.L., 2000.Verticillium wilt. The Plant Health Instructor.

Bhat R.G., Subbara o K.V., 1999. Host range specificity in Verticillium dahliae. Phytopathol., 89:1218-1225.

Chaleff R.S., 1983. Isolation of agronomically useful mutants from plant cell cultures. Science, 219: 676-682.

Damiano C., Monticelli S., Frattarelli A., Nicolini S., Corazza L., 1997. Somaclonal 
variability and in vitro regeneration of strawberry. Acta Hortic. 447:87-93.

Gordon T.R., Subbarao K.V., 2007. Production Guidelines: Verticillium wilt of strawberry. California Strawberry Commission.Issue 1.

Goth R.W., Webb R.E., 1981. Sources and genetics of host resistance in vegetable crops. In: Fungal Wilt Diseases of Plants (M.A. Mace, A.A. Bell and C.H. Beckman (eds.) New York, USA: Academic Press :377-411.

Graham J., 2005. Fragaria Strawberry. [In:] Litz R. (ed) Biotechnology of Fruit and Nut Crops. Biotechnology in Agriculture Series No. 29, CAB International, Wallingford,UK: 456-474.

Hammerschlag F., Garces S., Koch-Dean M., Ray S., Lewers K., Maas J., Smith B., 2006. In vitro response of strawberry cultivars and regenerants to Colletotrichum acutatum. Plant, Cell Tissue and Organ Culture, 84: 255-261.

J a in S . M ., 2001. Tissue culture-derived variation in crop improvement. Euphytica, 118: 153-166.

Jayas ankar S, Gray D. J., 2003. In vitro selection for disease resistance in plants an alternative to genetic engineering. AgBiotechNet. 5, ABN 111:5.

Larkin P.J., Scowcroft W.R., 1981. Somaclonal variation - a novel source of variability from cell cultures for plant improvement. Theor. Appl. Genet. 60:197214.

Larkin P. J., 1987. Somaclonal variation, history, method and meaning. Iowa St. J. Res. 61: 393-434.

Maas J.L., Zhong L., Galletta G.J.,1993. In vitro screening of strawberry plant and root cultures for resistance to Phytophthora fragariae and P.cactorum. Acta Hortic. 348: 496-499.

Moore P.P., Robbins J.A., Sjulin T.M., 1991. Field performance of 'Olympus' strawberry subclones. HortScience, 26: 192-194.

Murashige T., Skoog F.,1962. A revised medium for rapid growth and bioassays with tobacco tissue cultures. Physiol.Plant.15:473-497.

Orlando R., Magro P., Rugini E., 1997. Pectic enzymes as a selective pressure for in vitro recovery of strawberry plants with fungal disease resistance. Plant Cell Reports, 16: 272-276.

S owik I., 2001. Regeneracja in vitro pędów truskawki źródłem wariantów somaklonalnych odpornych na werticiliozę. Prace eksperymentalne. / In vitro regeneration of strawberry shoots as a source of somaclonal variants resistant to Verticillium wilt. Experimental work. Biotechnologia, 1: 131-133 (in Polish).

Sowik I., Bielenin A., Michalczuk L., 2001. In vitro testing of strawberry resistance to Verticillium dahliae and Phytophthora cactorum. Scientia Hortic. 88: $31-40$.

Sowik I., 2002. Badania nad metodami testowania wrażliwości truskawki na Verticillium dahliae w warunkach in vitro. Praca doktorska. / A study of testing methods for strawberry resistance to Verticillium dahliae under in vitro conditions. Doctoral thesis. ISK Skierniewice (in Polish).

Sowik I., Wawrzynczak D., Michalczuk L., 2003. Ex vitro establishment and greenhouse performance of somaclonal variants of strawberry selected for resistance to Verticillium dahliae. Acta Hortic., 616: 497-500.

Takahashi H., Takatsugu T., Tsutomu M., 1992. Resistant plants to Alternaria alternata strawberry pathotype selected from caliclones of strawberry cultivar Morioka-16 and their characteristics. J. Japan. Soc. Hort. Sci. 61: 323-329.

Toyoda H., Horikoshi K., Yamano Y., Ouchi S., 1991. Selection of Fusarium wilt disease resistance from regenerants derived from callus of strawberry. Plant Cell Reports, 10: 167-170.

Van den Bulk R.W.,1991. Application of cell and tissue culture and in vitro selection for disease resistance breeding - a review. Euphytica, 56: 269

Wilhelm S., 1981. Sources and genetics of host resistance in field and fruit crops. [In:] Fungal Wilt Diseases of Plants. M.A. Mace, A.A. Bell, C.H. Beckman (eds). New York, USA: Academic Press:.300-376.

Żurawicz, E., Masny A., 2005. Uprawa truskawek w polu i pod osłonami. Powszechne Wydawnictwo Rolnicze i Leśne: 32-33 (in Polish).

\section{Skuteczność selekcji odpornościowej na wertycyliozę w kulturze tkankowej truskawki (Fragaria x ananassa Duch.)}

\section{Streszczenie}

Patogeniczny grzyb glebowy Verticillium dahliae Kleb. powoduje ekonomiczne straty w uprawach roślin $\mathrm{w}$ regionach klimatu umiarkowanego, stąd też jest gatunkiem najbardziej badanym. Truskawka (Fragaria $\mathrm{x}$ ananassa Duch.) należy do gatunków roślin podatnych na Verticillium dahliae, chociaż reakcja na infekcję spowodowaną przez ten patogen jest zróżnicowana i zależy od odmiany. Ze względu na brak efektywnych metod eliminowania wertycyliozy, selekcja genetycznie odpornego materiału roślinnego jest priorytetowym kierunkiem w programach hodowli. W celu oceny skuteczności selekcji odpornościowej na wertycyliozę, badano reakcję na sztuczną infekcję spowodowaną przez Verticillium dahliae Kleb. w kulturze tkankowej dwóch odmian truskawki Filon i Teresa o zróżnicowanej podatności polowej na ten patogen. Kultura tkankowa była prowadzona przez 16 miesięcy w kontrolowanych warunkach fitotronu w temperaturze $18-20^{\circ} \mathrm{C}, 60-70 \%$ wilgotności względnej powietrza i intensywności światła wynoszącej

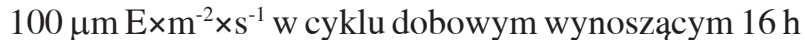
światło/8 h ciemność. Subkultury były pasażowane co 
6 tygodni na zmodyfikowanej pożywce Murashige'a i Skooga. Czterysta mikroroślin w obrębie dwóch subklonów uzyskanych zmerystemów każdejodmiany było inokulowanych w warunkach in vitro w stadium 4 . liści z wykorzystaniem płynnego homogenatu kultury grzyba Verticillium dahliae zastosowanego jako czynnik selekcyjny. Objawy chorobowe były obserwowane po $15^{\text {th }}, 30^{\text {th }}, 45^{\text {th }}, 60^{\text {th }}$ i $75^{\text {th }}$ dniach od inokulacji. Rozwój chlorozy liści był oceniany w skali od 0 do 4 . Po 75. dniach od inokulacji procentowy udział mikroroślinz całkowitą chlorozą w mikropropagowanej odmianie 'Teresa' osiągnął wartość $76.27 \%$, podczas gdy udział takich mikroroślin $\mathrm{w}$ inokulowanym subklonie odm. 'Filon' uzyskał wartość $89.40 \%$. Otrzymane wyniki wykazały wyższą genetyczną odporność kultury tkankowej odm.'Teresa' na zastosowany czynnik selekcyjny w porównaniu do selekcjonowanej kultury odm. Filon, gdyż zarówno procentowy udział całkowicie porażonych roślin, jak i obliczony dla selekcjonowanej kultury odm. Teresa indeks zakażeń przy całkowitym stopniu porażenia osiągnął niższe wartości $\mathrm{w}$ porównaniu z selekcjonowaną kulturą odm. Filon (odpowiednio 0.0962 i 0.1150 ). Zastosowana w badaniach procedura selekcji in vitro była wystarczająco efektywna dla określenia zróżnicowanej genetycznej odporności na Verticillium dahliae u dwóch ocenianych subklonów truskawki, gdyż wyniki uzyskane $\mathrm{w}$ testach odpornościowych in vitro były porównywalne $\mathrm{z}$ wynikami testów polowych, także wykazującymi mniejszą podatność na wertycyliozę odm.Teresa w stosunku do odm. Filon. Potwierdzona wynikami badań skuteczność testów odpornościowych in vitro $\mathrm{w}$ pełni uzasadnia ich stosowanie $\mathrm{w}$ programach hodowli. 